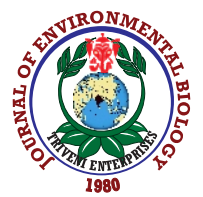

\title{
Effect of nitrate, ammonium and phosphate on the growth and microcystin production of Korean Microcystis species
}

\author{
J.H. Lee', K.L. Lee ${ }^{2}$, J.Y. Lee ${ }^{3}$ and H.S. Kim ${ }^{1 *}$ \\ ${ }^{1}$ Department of Biology, Kyungpook National University, Daegu, 41566, Republic of Korea \\ ${ }^{2}$ National Institute of Environmental Human Resources Development, Incheon,22689, Republic of Korea \\ ${ }^{3}$ National Institute of Environmental Research, Incheon, 22689, Republic of Korea \\ *Corresponding Author Email : kimhsu@knu.ac.kr
}

\section{Abstract}

Aim: This study aimed to investigate the effects of nitrogen $\left(\mathrm{NO}_{3}-\mathrm{N}, \mathrm{NH}_{3}-\mathrm{N}\right)$ and phosphorus $\left(\mathrm{PO}_{4}-\mathrm{P}\right)$ on the growth and microcystin production of two bloom-forming Microcystis species (toxic M. aeruginosa MAHC160824 and non-toxic M. viridis MVHC160824).

Methodology: The two Microcystis species were isolated from the lower reaches of the Nakdong River, South Korea. In the culture experiments, the average nutrient concentrations $\left(\mathrm{NH}_{3}-\mathrm{N}, \mathrm{NO}_{3}-\mathrm{N}\right.$ and $\left.\mathrm{PO}_{4}-\mathrm{P}\right)$ at which Microcystis appeared $\left(>15^{\circ} \mathrm{C}\right)$ was used as control medium. Different concentrations of $\mathrm{NH}_{3}-\mathrm{N}, \mathrm{NO}_{3}-\mathrm{N}$ and $\mathrm{PO}_{4}-\mathrm{P}$ were then employed in nutrient testing (control, vs. 4 times and 16 times higher than the control). Microcystin levels were measured using a UPLC ${ }^{\text {TI }}$ (LCMS/MS) system.

Results: Both toxic and non-toxic Microcystis strains exhibited a maximum cell density at $30^{\circ} \mathrm{C}$ and a maximum growth rate at $25-30^{\circ} \mathrm{C}$. In the nutrient addition assays, the maximum growth of two Microcystis species were found at nutrient concentrations 4 to 16 times higher than the control $\left(\mathrm{NH}_{3}-\mathrm{N}\right.$ : $\left.0.468 \mathrm{mg} \mathrm{l}^{-1}, \mathrm{PO}_{4}-\mathrm{P}: 0.100 \mathrm{mg} \mathrm{l}^{-1}, \mathrm{NO}_{3}-\mathrm{N}: 32.5 \mathrm{mg} \mathrm{l}^{-1}\right)$. The highest microcystin production levels were found under optimal growth conditions. The microcystin levels of toxic $M$. aeruginosa MAHC160824 were below the detection limit despite a higher number of cells (> 300,000 cells $\left.\mathrm{ml}^{-1}\right)$ at the same nutrients concentrations as those found in raw water from the Nakdong River.

Interpretation: Higher production of microcystin occurs when there is an increase in $\mathrm{NH}_{3}-\mathrm{N}$ and $\mathrm{PO}_{4}-\mathrm{P}$ within a restricted range in toxic species $M$. aeruginosa MAHC160824, else the production is low.

Keywords: Microcystins, Microcystis species, Nakdong River, Nitrogen, Phosphorus
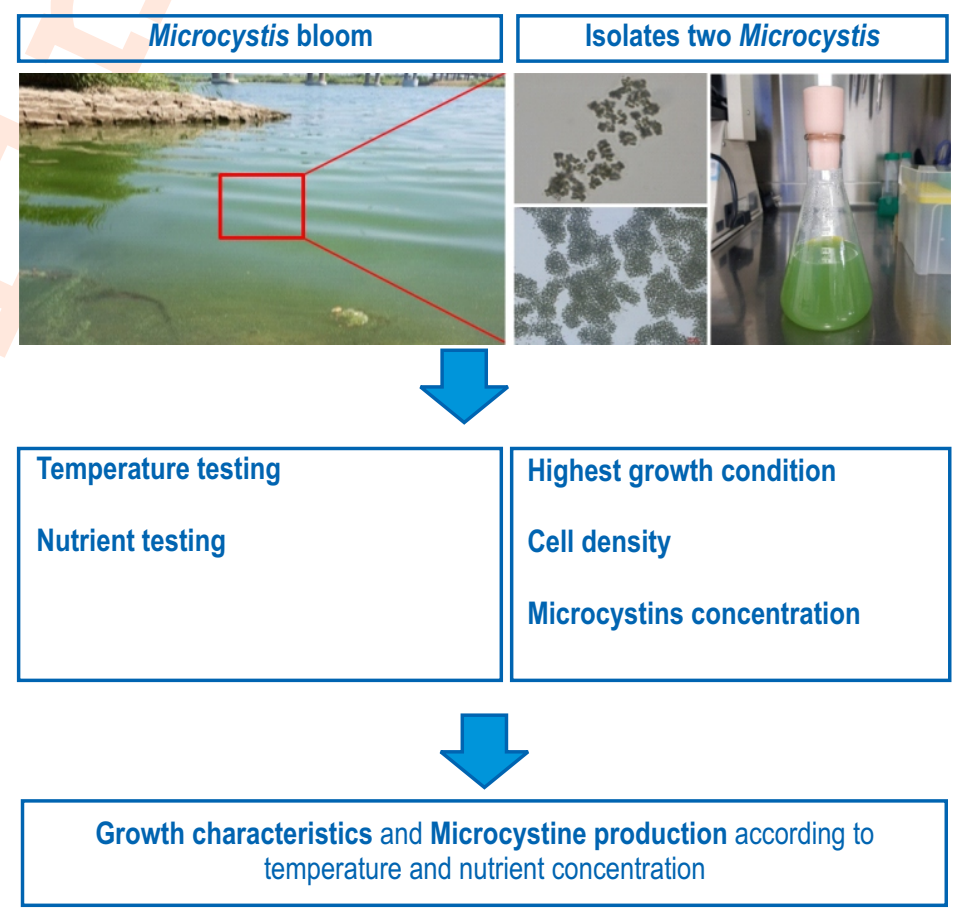

How to cite : Lee, J.H., K.L. Lee, J.Y. Lee and H.S. Kim: Effect of nitrate, ammonium and phosphate on the growth and microcystin production of Korean Microcystis species. J. Environ. Biol., 41, 812-820 (2020). 


\section{Introduction}

Climate change, global warming, urbanization and industrialization has numerous deleterious impacts on the environment globally, one of them include higher occurrence of toxic cyanobacteria in freshwater ecosystems (Sabour et al., 2002; Kemp and John, 2006). Cyanobacterial blooms depletes dissolved oxygen and produces toxins and odor leading to direct and indirect damage to aquatic organisms and humans. Toxic cyanobacteria produces cyanotoxins such as microcystin, anatoxin-a and cylindrospermopsins that can interact with environmental conditions and pose a negative effect on human body, causing diarrhea, vomiting, headaches and skin disease. As such, to ensure safety of drinking water, the World Health Organization has proposed a permissible limit of $1 \mu \mathrm{gl}^{-1}$ for most toxic microcystin, microcystin-LR (WHO, 2017). Microcystis is a common toxic cyanobacterium that produce microcystins, and causes aquatic blooms during summers in South Korea (Lee et al., 2008; Lee et al., 2018). Generally, the production of microcystins is determined by environmental factors (Hesse et al., 2001; Long et al., 2001), and Microcystis is reported to exhibit species and strain specific growth and toxin production based on environmental factors such as temperature, light intensity and nutrient concentration (Graham et al., 2004; Giani et al., 2005). As a result, microcystin levels can be detected depending on the composition of Microcystis species in an ecosystem based on their physiological and ecological responses to various environmental factors (Via-Ordorika et al., 2004; Lee et al., 2008; Lee et al., 2018). Particularly, in temperate regions, the ratio of toxic and non-toxic Microcystis species vary with water temperature and nutrient concentration, which affects the temporal and spatial distribution of microcystins (Graham et al., 2004; Giani et al., 2005; Davis et al., 2009). For example, it has been reported that species that can potentially produce microcystins exhibit an increase in frequency and composition in water bodies subject to eutrophication (Rantala et al., 2006). Of particular concern in this regard is nitrogen and phosphorus, which can enter water bodies from point or non-point pollutants, and facilitate Microcystis blooms leading to higher production of microcystins (Harke et al., 2012). Indeed, phosphorus and various forms of nitrogen have been identified as main factors affecting the growth of Microcystis and microcystin production (Paerl et al., 2011). Although previous studies on microcystin production have been conducted, species or strain specific research related to growth and microcystin production of Microcystis are meagre. In Korea, the Nakdong River supplies drinking water to about 13 million people in major cities such as Daegu and Busan. Eight multipurpose weirs have been built along the Nakdong River, increasing the water retention time and consequently promoting Microcystis blooms and anthropogenic eutrophication in the middle and lower reaches of the river. Two bloom-forming Microcystis species ( $M$. aeruginosa and $M$. viridis) responsible for these blooms in the Nakdong River were isolated in the present study. Culture experiments were conducted to evaluate the characteristics of microcystin production in relation to growth response to variation in water temperature and nitrogen and phosphorus concentration.

\section{Materials and Methods}

Sampling, identification and isolation: The samples were collected at the Hapcheon-Changnyeong weir section of the

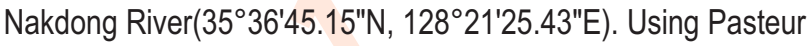
pipettes, a single culture could be obtained by re-isolating species form the sample several times. Species were identified using a light microscope (Axio Imager M2, Zeiss, Germany), based on Komárek and Anagnostidis (2008). The mcyAgene was identified to distinguish the toxic and non-toxic species. The primers used were MSF (5'-ATCCAGCAGTTGAGC AAGC-3') and MSR (5'TGCAGATAACT CCGCAGTTG-3') (Tillett et al., 2001).

Experimental conditions: All culture experiments were conducted using $\mathrm{CB}$ medium in $250 \mathrm{ml}$ flasks. Unialgal stock cultures were maintained in $\mathrm{CB}$ medium (adjusted to $\mathrm{pH} 9.0$ with a carbon free $\mathrm{NaOH}$ buffer) at $25 \pm 1^{\circ} \mathrm{C}$ and a light intensity of ca. 30 $\mu \mathrm{mol} \mathrm{m} \mathrm{m}^{-2}$ under a 16:8 light/dark cycle. Cells of two species in their exponential growth phase were inoculated into each test medium to produce a density of approximately 2,000 cells $\mathrm{m} \mathrm{l}^{-1}$. For culture experiments, clones were selected from the stock cultures during the exponential growth phase. Incubation experiment was conducted at $15^{\circ} \mathrm{C}, 20^{\circ} \mathrm{C}, 25^{\circ} \mathrm{C}$ and $30^{\circ} \mathrm{C}$ to identify differences in growth and microcystin production according to temperature. For nutrient testing, $\mathrm{NH}_{3}-\mathrm{N}, \mathrm{NO}_{3}-\mathrm{N}$ and $\mathrm{PO}_{4}-\mathrm{P}$ were adjusted based on the composition of $\mathrm{CB}$ medium, and the average nutrient concentration during Microcystis appeared $\left(>15^{\circ} \mathrm{C}\right.$, three-year average nutrients concentrations is $\mathrm{NO}_{3}-\mathrm{N} 2.033 \mathrm{mgl}^{-1}, \mathrm{NH}_{3}-\mathrm{N} 0.117 \mathrm{mgl}^{-1}$ and $\mathrm{PO}_{4}-\mathrm{P} 0.025 \mathrm{mgl}^{-1}$ ) was used as control medium (Table 1). Different concentrations of $\mathrm{NH}_{3}-\mathrm{N}, \mathrm{NO}_{3}-\mathrm{N}$ and $\mathrm{PO}_{4}-\mathrm{P}$ were then employed for testing (control, vs. 4 times and 16 times higher than the control) $\mathrm{Ca}\left(\mathrm{NO}_{3}\right) 4 \mathrm{H}_{2} \mathrm{O}+$ $\mathrm{KNO}_{3}, \mathrm{NH}_{4} \mathrm{Cl}$ and $\beta-\mathrm{Na}_{2}$ glycerophosphate were used as source for $\mathrm{NO}_{3}-\mathrm{N}, \mathrm{NH}_{3}-\mathrm{N}$ and $\mathrm{PO}_{4}-\mathrm{P}$.

Nutrient testing lasted for three weeks under the following conditions: $\mathrm{pH} 9.0,30 \pm 1^{\circ} \mathrm{C}$ and ca. $30 \mu \mathrm{mol} \mathrm{m} \mathrm{m}^{-2} \mathrm{~s}^{-1}$ with a $16: 8$ light/dark cycle. All experiments were carried out in triplicate and cell numbers were determined using a Sedgewick Rafter Chamber following sonication (30 W, $10 \mathrm{sec;}$ ULH-700S, Jeiotech, Korea). The growth rate was calculated by the equation $\mu=\left(\ln N_{2}-\ln N_{1}\right) /\left(t_{2}-t_{1}\right)$, where $N_{2}$ and $N_{1}$ are the number of cells during growth period at time $t_{2}$ and $t_{1}$.

Microcystin analysis: After incubating toxic Microcystis aeruginosa MAHC160824, cell samples were harvested from the lag phase (6 day), exponential phase (12 day) and stationary phase (18 day) and used for toxin analysis. For total microcystin analysis, $40 \mathrm{ml}$ of samples were harvested from each growth 
Table 1: Composition of CB medium and control medium used in this study

\begin{tabular}{|c|c|c|}
\hline Component & $\mathrm{CB}$ medium & Control medium \\
\hline 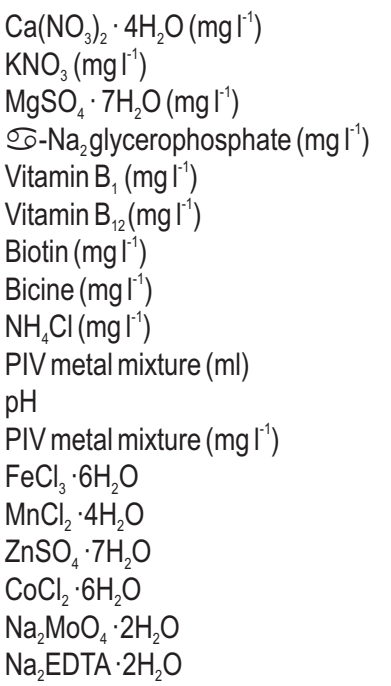 & $\begin{array}{l}150 \\
100 \\
40 \\
50 \\
0.01 \\
0.0001 \\
0.0001 \\
500 \\
0 \\
3 \\
9.0 \\
196 \\
36 \\
22 \\
4 \\
2.5 \\
1000\end{array}$ & $\begin{array}{l}12.16 \\
6.57 \\
40 \\
0.25 \\
0.01 \\
0.0001 \\
0.0001 \\
500 \\
0.38 \\
3 \\
9.0\end{array}$ \\
\hline
\end{tabular}

phase. For total microcystin analysis, $20 \mathrm{ml}$ of samples containing cell pellets were homogenized using sonication (30 W, $10 \mathrm{sec}$; ULH-700S, Jeiotech, Korea) and the homogenized samples were then filtered through a GF/C filter $(1.2 \mu \mathrm{m})$. For extracellular microcystin analysis, $20 \mathrm{ml}$ of culture samples were directly filtered through a GF/C filter $(1.2 \mu \mathrm{m})$ without sonication. Following this, total and extracellular microcystin levels were measured using an ultra performance liquid chromatography (UPLC ${ }^{\text {Tw}}$ ) system (ACQUITY UPLC I-Class, Waters Corporation, MA, USA) after filtering through a syringe filter $(0.2 \mu \mathrm{m})$. Microcystin standards (-LA, -LR, -RR, -YR) were used to analyze the four types of microcystin present in the samples. These were assessed using the UPLC ${ }^{\text {Tw }}$ system, with $10 \mu$ l samples injected into the Waters BEH C1 8 column of a $0.2 \mu \mathrm{m}$ precolumn filter. The column was maintained at $40^{\circ} \mathrm{C}$ and flow rate of $400 \mu \mathrm{l} \mathrm{min}{ }^{-1}$. The mobile phase consisted of water $(A)$ and acetonitrile $(B)$, and was set to $0 \%$ B for $0.5 \mathrm{~min}, 30 \%$ B for $2.5 \mathrm{~min}, 65 \%$ B for $4.5 \mathrm{~min}, 40 \%$ $\mathrm{B}$ for $5 \mathrm{~min}, 80 \% \mathrm{~B}$ for $6 \mathrm{~min}, 0 \% \mathrm{~B}$ for $6.5 \mathrm{~min}$ and $0 \% \mathrm{~B}$ for $8 \mathrm{~min}$. Microcystins were qualitatively and quantitatively analyzed using a Xevo TQ-S detector system (Waters Corporation, Manchester, UK) with electrospray ionization (ESI) connected to the UPLC ${ }^{\mathrm{TM}}$ system. At positive mode (ES+), multiple action monitoring (MRM) was monitored using collision of argon gas with the samples. The flow rate of argon gas was $150 \mathrm{hr}^{-1}$ at $150^{\circ} \mathrm{C}$. The flow rate of nitrogen gas, which was used as a de-solvent, was $800 \mathrm{hr}^{-1}$ at $400^{\circ} \mathrm{C}$. MassLynx software (Waters Corporation) was used to analyze the results.

Statistical analyses: Statistical significance among the explanatory variables was confirmed by one-way ANOVA and post hoc Tukey's honestly significant difference (HSD) tests using SPSS 12.0 software.

\section{Results and Discussion}

The genus Microcystis was dominant in 78 of the 240 phytoplankton samples collected from the lower reaches of Nakdong River (water.nier.go.kr). At this point, the cell density was 309,800 cells $\mathrm{ml}^{-1}$ at water temperature of $30.6^{\circ} \mathrm{C}$. In the present study, the density of two bloom-forming Microcystis strains were 17,500 cells $\mathrm{ml}^{-1}$ at $15^{\circ} \mathrm{C}$ and 207,500 cells $\mathrm{ml}^{-1}$ at $30^{\circ} \mathrm{C}$ in the control medium which maintained the same nutrient concentrations as those found in field water. These results indicate that a higher water temperature can cause Microcystis blooms involving both toxic and non-toxic species. The cell density of toxic $M$. aeruginosa MAHC160824 and non-toxic $M$. viridis MVHC160824 increased with temperature over the tested range, and the maximum cell density 207,500 cells $\mathrm{ml}^{-1}$ and 107,000 cells $\mathrm{ml}^{-1}$ was observed at $30^{\circ} \mathrm{C}$ (Fig. 1, A1, B1). The maximum growth rates of both species were observed at $25^{\circ}$ $30^{\circ} \mathrm{C}$ (Fig. 1, A2, B2).

The following nutrient experiments were conducted at $30^{\circ} \mathrm{C}$. Both toxic $M$. aeruginosa MAHC160824 and non-toxic $M$. viridis MAHC160824 attained the growth threshold at $\mathrm{PO}_{4}-\mathrm{P}$ concentration, four times higher than that of the control (Fig. 2, A1-A4). For the given $\mathrm{NH}_{3}-\mathrm{N}$ range, the two strains attained the maximum growth at $\mathrm{NH}_{3}-\mathrm{N}$ concentration four times higher than that of the control (Fig. 2, B1-B4). The two Microcystis strains exhibited a higher cell density with increasing $\mathrm{NO}_{3}-\mathrm{N}$ concentration, and also showed a maximum cell density and growth rate at a concentration 16 times higher than that of the control (Fig. 2, C1-C4).

In the nutrient testing, the two Microcystis strains reached the growth threshold four times higher the concentration than that 

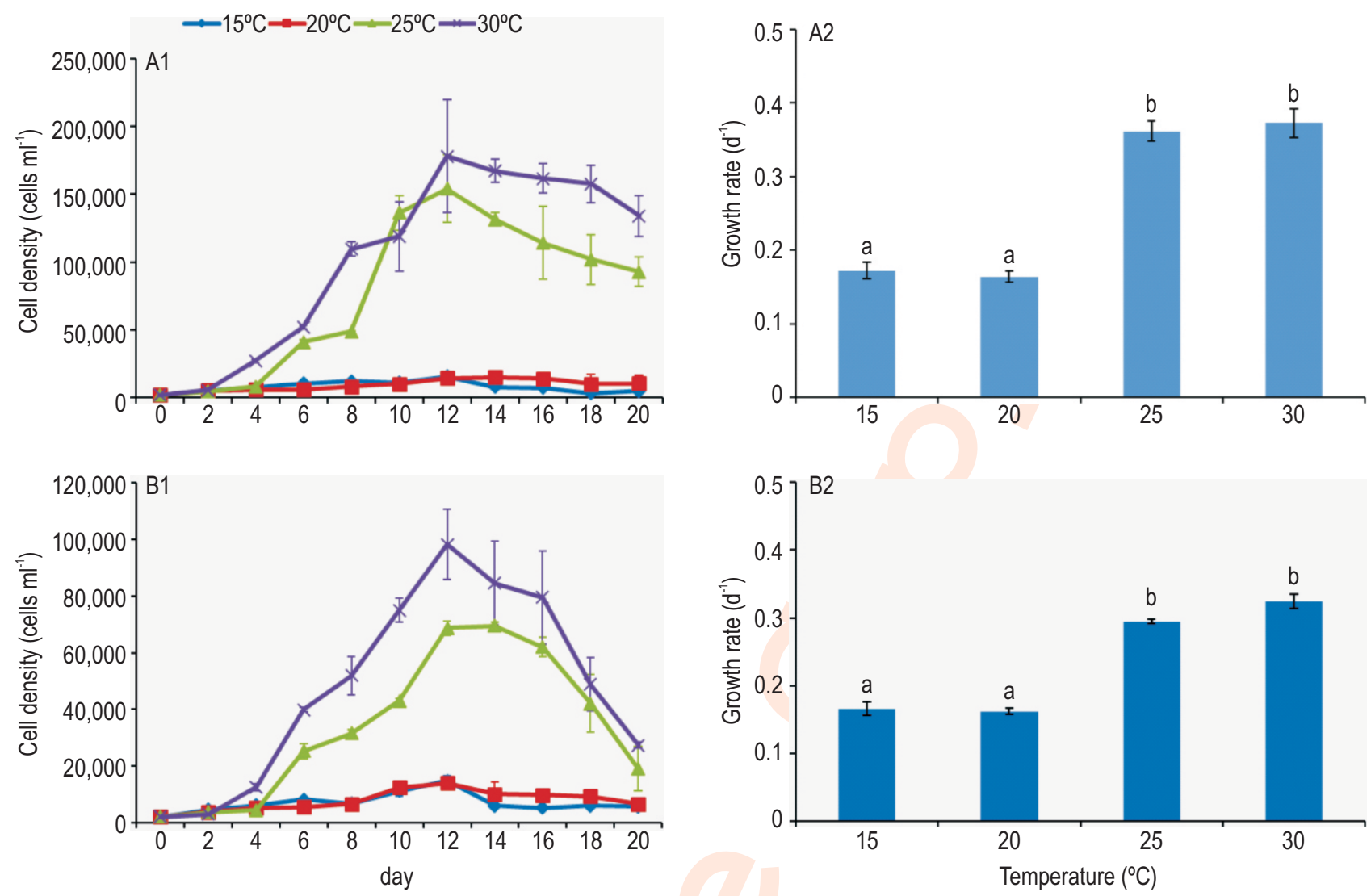

Fig. 1: Growth characteristics and growth rates of toxic M. aeruginosa MAHC160824 (A1, A2) and non-toxic M. viridis MVHC160824 (B1, B2) according to temperature. All values are given as the mean \pm standard deviation $(n=3)$. Differences between the treatments are shown based on Tukey's HSD tests $(a<b, p<0.05)$.

of the control $\left(\mathrm{NH}_{3}-\mathrm{N}: 0.468 \mathrm{mg} \mathrm{l}^{-1}, \mathrm{PO}_{4}-\mathrm{P}: 0.1 \mathrm{mg} \mathrm{l}^{-1}\right)$ and a significantly higher cell density was achieved at nitrate concentration 16 times higher than that of the control $\left(\mathrm{NO}_{3}-\mathrm{N}\right.$ : $32.5 \mathrm{mg} \mathrm{l}^{-1} ;$; Fig. 2). These results suggest that $\mathrm{NH}_{3}-\mathrm{N}$ and $\mathrm{PO}_{4}-\mathrm{P}$ in the lower reaches of the Nakdong River have a stronger influence on the formation of toxic and non-toxic Microcystis blooms than $\mathrm{NO}_{3}-\mathrm{N}$ at higher water temperature. Moreover, they indicated that $\mathrm{NH}_{3}-\mathrm{N}$ and $\mathrm{PO}_{4}-\mathrm{P}$ may be found near the threshold concentrations required for Microcystis growth in the lower reaches of the Nakdong River. Harke et al. (2012) suggested that Microcystis exhibits high $\mathrm{PO}_{4}^{3-}$ uptake rate due to increased phosphatase activity at low phosphorus levels due to high phosphorus affinity. In the $\mathrm{PO}_{4}-\mathrm{P}$ culture testing, the two Microcystis strains maintained a similar cell density at all concentrations during stationary phase (Fig. 2, A1-A4). This demonstrates that Microcystis has growth potential within a limited phosphorus range in the Nakdong River. In other words, our findings suggest that reducing the levels of phosphorus would not control Microcystis blooms in the Nakdong River. In fact, the standards for total phosphorus effluent discharge in large rivers like the Nakdong River is $0.2 \mathrm{mg} \mathrm{l}^{-1}$ in South Korea (Kim et al., 2010), which far exceeds the phosphorus range required to control Microcystis blooms.
Recent studies have suggested that along with phosphorus various forms of nitrogen affect the growth of Microcystis (Baldia et al., 2007; Pearl et al., 2011; Li et al., 2016). Nitrogen availability during summers is an important factor limiting the growth of Microcystis (Šejnohová and Maršálek, 2012). $\mathrm{NH}_{3}-\mathrm{N}$ and $\mathrm{NO}_{3}-\mathrm{N}$ in particular are the most important nitrogen sources affecting Microcystis growth. According to $\mathrm{Li}$ et al. (2016), M. aeruginosa exhibits a steady increase in proportion to the concentration of $\mathrm{NO}_{3}-\mathrm{N}\left(1.2-6.0 \mathrm{mg} \mathrm{l}^{-1}\right)$, while growth was lower at $1.2 \mathrm{mgl}^{-1} \mathrm{NH}_{3}-\mathrm{N}$. This means that $\mathrm{NH}_{3}-\mathrm{N}$ uptake is faster than $\mathrm{NO}_{3}-\mathrm{N}$ and it can grow faster in $\mathrm{NH}_{3}-\mathrm{N}$, which is more limiting than $\mathrm{NO}_{3}-\mathrm{N}$ (Li et al., 2016). Baldia et al. (2007) reported that $M$. aeruginosa had a low rate of uptake for $\mathrm{NO}_{3}-\mathrm{N}$ but reached growth saturation at a relatively high concentration of $8.71 \mathrm{mg} \mathrm{l}^{-1}$, indicating high $\mathrm{NO}_{3}-\mathrm{N}$ requirements. In the present study, growth saturation was not observed in the given $\mathrm{NO}_{3}-\mathrm{N}$ range (2.033$32.53 \mathrm{mg} \mathrm{l}^{-1}$ ) in the two Microcystis strains (Fig. 2, C1-C4). This suggests that both strains isolated from the Nakdong River may reach growth saturation, maximum growth at much higher $\mathrm{NO}_{3}-\mathrm{N}$ levels than those present in field water. Generally, cyanobacteria, including Microcystis, prefer $\mathrm{NH}_{3}-\mathrm{N}$ to $\mathrm{NO}_{3}-\mathrm{N}$. Unlike $\mathrm{NH}_{3}-\mathrm{N}$, which is directly available to cells, $\mathrm{NO}_{3}-\mathrm{N}$ is reduced to intermediate compounds such as ammonium and amino acids 

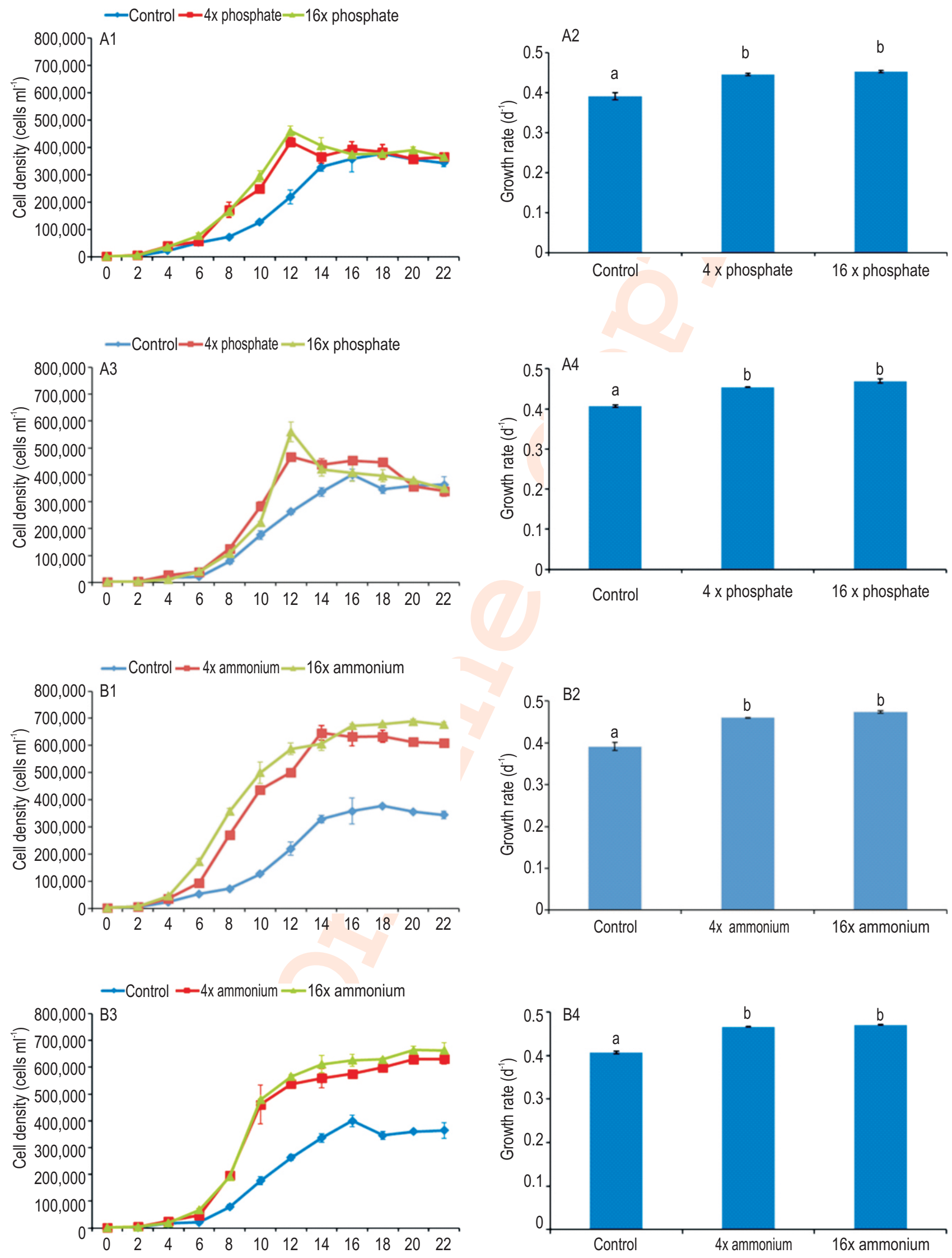

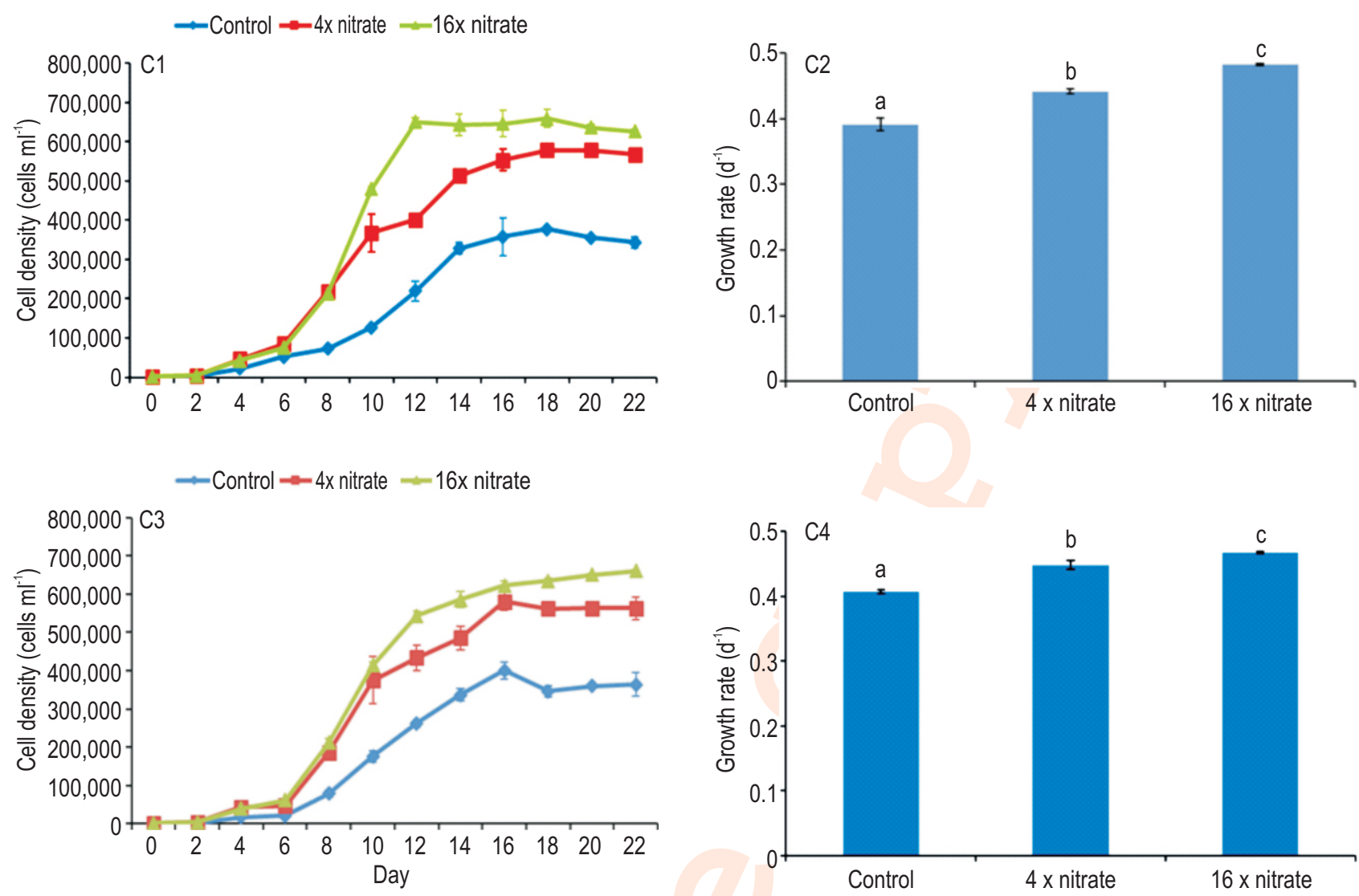

Fig. 2 : Cell density of toxic M. aeruginosa MAHC160824 and non-toxic M. viridis MVHC160824 according to phosphate (PO $-\mathrm{P}: \mathrm{A} 1, \mathrm{~A} 3)$, ammonium $\left(\mathrm{NH}_{3}-\mathrm{N}: \mathrm{B1}, \mathrm{B} 3\right)$ and nitrate $\left(\mathrm{NO}_{3}-\mathrm{N}: \mathrm{C} 1, \mathrm{C} 3\right)$ concentration and the growth rate of toxic M. aeruginosa MAHC160824 and non-toxic M. viridis MVHC160824 according to phosphate ( $\left.\mathrm{PO}_{4}-\mathrm{P}: \mathrm{A} 2, \mathrm{~A} 4\right)$, ammonium $\left(\mathrm{NH}_{3}-\mathrm{N}: \mathrm{B} 2, \mathrm{~B} 4\right)$ and nitrate $\left(\mathrm{NO}_{3}-\mathrm{N}: \mathrm{C} 2, \mathrm{C} 4\right)$ concentration. All values are given as the mean \pm standard deviation. Differences between the treatments are shown based on Tukey's HSD tests $(a<b<c, p<0.05)$.

(Von Rückert and Giani, 2004). Therefore, Microcystis can reach growth saturation more rapidly using $\mathrm{NH}_{3}-\mathrm{N}$, even in limiting conditions. In the growth experiments, based on nutrient concentrations, the present study confirmed that the two Microcystis strains could reach growth saturation within an $\mathrm{NH}_{3}-\mathrm{N}$ and $\mathrm{PO}_{4}-\mathrm{P}$ concentration range that was similar to raw water. Given the results of our research and previous studies, $\mathrm{NH}_{3}-\mathrm{N}$ and $\mathrm{PO}_{4}-\mathrm{P}$ can be classified as strongly synergistic limiting factors for Microcystis growth in the Nakdong River during summer.

M. aeruginosa MAHC160824 was tested to determine microcystin production at different temperatures and nutrient levels $\left(\mathrm{NO}_{3}-\mathrm{N}, \mathrm{NH}_{3}-\mathrm{N}, \mathrm{PO}_{4}-\mathrm{P}\right)$. The concentration of microcystins in the control medium was below the limit of detection (LOD), as was the case for field water. Dissolved, extracellular microcystins were also below the LOD in all experimental conditions. Of the four microcystin variants (-LA, -LR, -RR, -YR), microcystin-LA was not detected. Lee et al. (2018) reported that microcystin-LA was not detected. Total intracellular microcystins and intracellular microcystin-LR in the culture medium reached their maximum levels for $\mathrm{M}$. aeruginosa MAHC160824 at a $\mathrm{PO}_{4}-\mathrm{P}$ concentration four times higher than that of the control group during stationary phase (18 days; Fig. 3, A1,A2). Total intracellular microcystins per cell were also highest when the $\mathrm{PO}_{4}-\mathrm{P}$ concentration was four times higher than that of the control group during stationary phase (18 days), while intracellular microcystin-LR per cell was highest at $\mathrm{PO}_{4}-\mathrm{P}$ concentration four times higher that of control during lag phase ( 6 days). For $\mathrm{NH}_{3}-\mathrm{N}$, the concentration of total intracellular microcystins and intracellular microcystin- $\mathrm{LR}$ was highest at $\mathrm{NH}_{3}$ $\mathrm{N}$ concentration four times that of the control during stationary phase (18 days; Fig. 3, B1, B2). Total intracellular microcystin and intracellular microcystin-LR per cell was also highest at four times the $\mathrm{NH}_{3}-\mathrm{N}$ concentration of the control during stationary phase (18 days). For $\mathrm{NO}_{3}-\mathrm{N}$, total intracellular microcystin and intracellular microcystin-LR levels increased in a manner similar to the growth response to $\mathrm{NO}_{3}-\mathrm{N}$ concentration, demonstrating the highest levels during stationary phase (18 days) at $\mathrm{NO}_{3}-\mathrm{N}$ concentration 16 times higher than that of the control (Fig. 3, C1, C2). Total intracellular microcystin and intracellular microcystinLR per cell was also highest under these conditions (Fig. 3). 

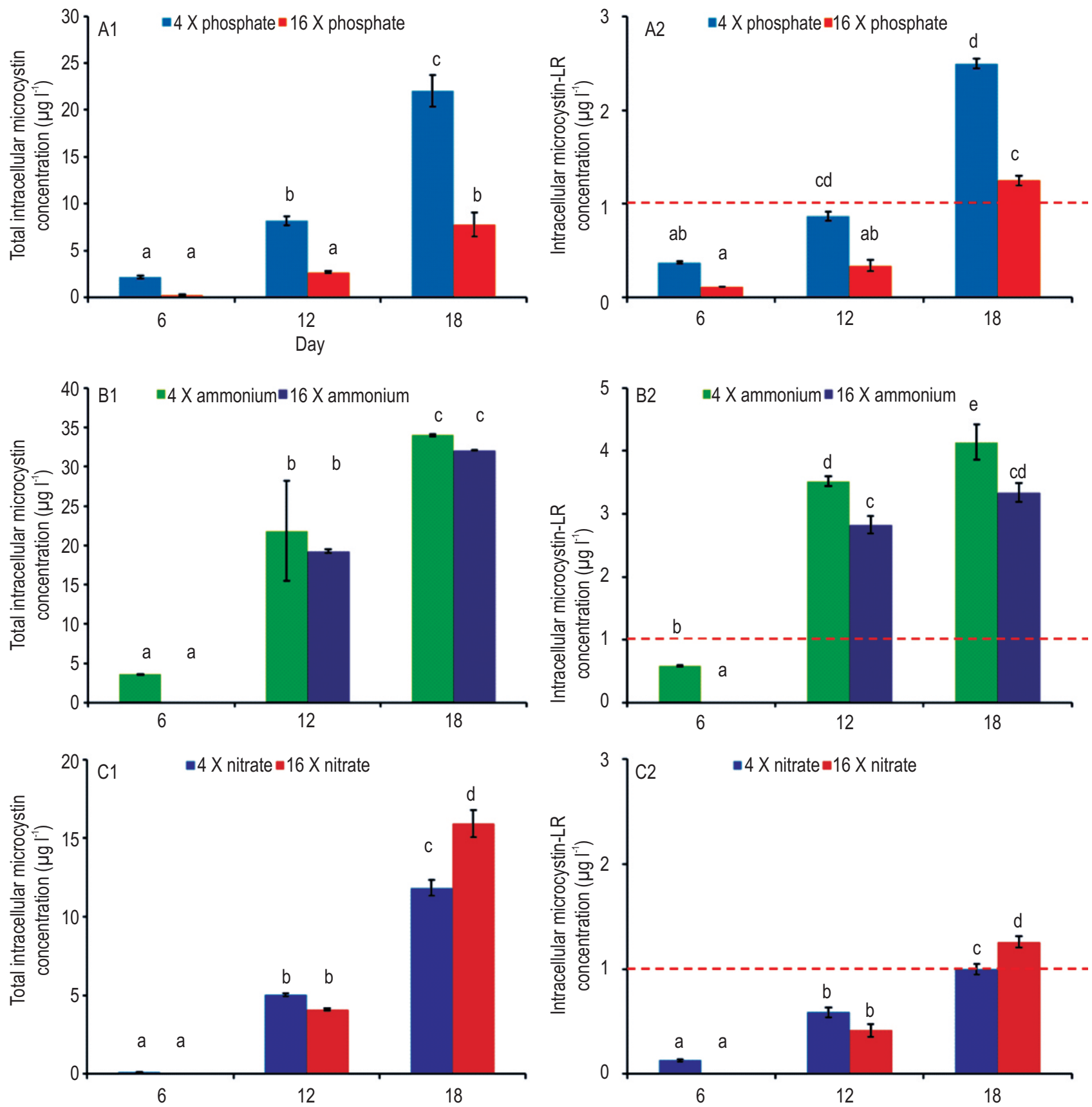

Fig. 3 : Total microcystin (A1, B1, C1) and microcystin-LR (A2, B2, C2) for M. aeruginosa MAHC160824 according to phosphate (PO $-P$ : $A 1, A 2)$, ammonium $\left(\mathrm{NH}_{3}-\mathrm{N}: \mathrm{B} 1, \mathrm{~B} 2\right)$ and nitrate $\left(\mathrm{NO}_{3}-\mathrm{N}: \mathrm{C1}, \mathrm{C} 2\right)$ concentration. All values are given as the mean \pm standard deviation. Differences between the treatments are shown based on Tukey's HSD tests $(a<b<c<d<e, p<0.05)$. The red line indicates WHO guidelines for microcystin-LR in safe drinking water.

In contrast, in the present study, no microcystins were detected from the toxic M. aeruginosa MAHC16082 under any of the temperature conditions $\left(15,20,25,30^{\circ} \mathrm{C}\right)$, despite relatively high cell numbers in the control medium (Fig. 3 ), because the temperature experiment was conducted based on the nutrient concentrations $\left(\mathrm{NO}_{3}-\mathrm{N}, \mathrm{NH}_{3}-\mathrm{N}, \mathrm{PO}_{4}-\mathrm{P}\right)$ present in the field water of Nakdong River. This suggests that microcystin production in the Microcystis strains isolated from the Nakdong River is primarily affected by nutrient levels. Interestingly, despite regular occurrence of Microcystis blooms, the detection frequency and concentration of microcystins are low in the Nakdong River (water.nier.go.kr). Therefore, it is hypothesized that the concentration of nutrients $\left(\mathrm{NO}_{3}-\mathrm{N}, \mathrm{NH}_{3}-\mathrm{N}\right.$ and $\left.\mathrm{PO}_{4}-\mathrm{P}\right)$ in the Nakdong River may not be at a level high 
enough to affect microcystin production.

In the nutrient culture experiments, $M$. aeruginosa MAHC160824 exhibited markedly high microcystin production when growth reached its stationary phase, on adding reported $\mathrm{NO}_{3}-\mathrm{N}, \mathrm{NH}_{3}-\mathrm{N}$ and $\mathrm{PO}_{4}-\mathrm{P}$. This is similar to the results reported by Long et al. (2001), who reported that microcystin production per cell was maximum when the growth rate of $M$. aeruginosa was zero. According to Lyck (2004), the intracellular microcystin level of $M$. aeruginosa are higher at early stages of growth, but decrease during exponential growth stage, suggesting the possible release of extracellular microcystin. In the present study, extracellular microcystins were below the LOD. Our results show that $\mathrm{NH}_{3}-\mathrm{N}$ and $\mathrm{PO}_{4}-\mathrm{P}$ simultaneously affected the growth and microcystin production of toxic $M$. aeruginosa MAHC160824 within a restricted nutrient range. Within the limited range of $\mathrm{NH}_{3}-\mathrm{N}$ and $\mathrm{PO}_{4}-\mathrm{P}$ concentrations observed in the field, $M$. aeruginosa can produce blooms and maximize toxin production (Dai et al., 2008, Gobler et al., 2016). In this study, microcystin production was below the LOD regardless of cell density at all growth stages when nutrient concentrations $\left(\mathrm{NO}_{3}-\mathrm{N}, \mathrm{NH}_{3}-\mathrm{N}\right.$ and $\left.\mathrm{PO}_{4}-\mathrm{P}\right)$ were same as those in the water sampled from the Nakdong River (Fig. 3). Although these results are based on the culture of a specific toxic strain, it is suggested that $M$. aeruginosa had low microcystin production under the nutrient concentrations present in the Nakdong River at the time of sampling, i.e., during blooming season $\left(\mathrm{NO}_{3}-\mathrm{N}: 2.033\right.$ $\left.\mathrm{mg} \mathrm{I}^{-1}, \mathrm{NH}_{3}-\mathrm{N}: 0.117 \mathrm{mg} \mathrm{I}^{-1}, \mathrm{PO}_{4}-\mathrm{P}: 0.025 \mathrm{mg} \mathrm{I}^{-1}\right)$. Interestingly, microcystin detection was infrequent during Microcystis blooms in the Nakdong River in 2016, and the concentration of nutrients were similar to or lower than those in the control medium.

In the case of $\mathrm{PO}_{4}-\mathrm{P}$, Microcystin production was highest at $\mathrm{PO}_{4}-\mathrm{P}$ concentrations 4 times higher than of the control (Fig. 3 A1, A2). Peng et al. (2018) suggested that the inorganic phosphorus source was more useful for Microcystis and results in the highest growth when the N:P ratio was 16-30. Although in this study, using dissolved organic phosphorus as a source, the N:P ratio of the experiment that increased $\mathrm{PO}_{4}-\mathrm{P} 4$ times was about 20:1 (16 times that of the control was 5:1). Increasing phosphorus did not significantly affect cell growth, but it was demonstrated that the appropriate $\mathrm{N}: \mathrm{P}$ ratio affected microcystin production. When the phosphorus was increase four times the $\mathrm{N}: \mathrm{P}$ ratio $(1$ : 4), the oxidative stress and lipid peroxidation of cell membrane and photosynthetic activity decreased consequently. Field and culture research have demonstrated that biologically available nitrogen has a direct impact on microcystin production (Downing et al., 2005; Scott et al., 2013; Horst et al., 2014). In particular, $\mathrm{NH}_{3}-\mathrm{N}$ directly affects the microcystin production in the form of dissolved inorganic nitrogen, which can be used directly by the members of this genus (Dai et al., 2008; Gobler et al., 2016). In oligotrophic lakes, microcystin-producing species are uncommon, however, eutrophic lakes, which contain higher nitrogen levels, are more likely to contain these species (Rantala et al., 2006). Horst et al. (2014) also suggested that $\mathrm{NO}_{3}-\mathrm{N}$ availability greatly influences microcystin production. In accordance with these studies, addition of $\mathrm{NO}_{3}-\mathrm{N}$ and $\mathrm{NH}_{3}-\mathrm{N}$ increased microcystin production in the present study. When $\mathrm{NO}_{3}$ $\mathrm{N}$ concentration increased from 4 to 16 times higher than that of the control, the cell density and microcystin concentration increased simultaneously (Fig. 2, C1, C2; Fig. 3, C1, C2). However, saturation of microcystin production with increasing $\mathrm{NO}_{3}-\mathrm{N}$ was not observed. The present study, thus, revealed that toxic $M$. aeruginosa MAHC160824 produces higher microcystin concentration more efficiently with $\mathrm{NH}_{3}-\mathrm{N}$ than with $\mathrm{NO}_{3}-\mathrm{N}$ within a restricted nutrient range. Our results found that microcystins levels were lower than LOD, even though the growth of toxic $M$. aeruginosa MAHC160824 was relatively high under control conditions that corresponded to those of field water from the Nakdong River.

The results, toxic $M$. aeruginosa in the Nakdong River exhibited relatively low microcystin production. However, if nitrogen and phosphorus level rises above the average concentration during Microcystis blooming seasons, it is expected to produce higher concentration of microcystins. Further research is required to determine whether these characteristics are specific to toxic Microcystis strains present in the Nakdong River.

\section{References}

Baldia, S.F., A.D. Evangelista, E.V. Aralar and A.E. Santiago: Nitrogen and phosphorus utilization in the cyanobacterium Microcystis aeruginosa isolated from Laguna de Bay, Philippines. J. Appl. Phycol., 19, 607-613 (2007).

Dai, R., H. Liu, J. Qu, X. Zhao, J. Ru and Y. Hou: Relationship of energy charge and toxin content of Microcystis aeruginosa in nitrogenlimited or phosphorus-limited cultures. Toxicon, 51, 649-658 (2008).

Davis, T.W., D.L. Berry, G.L. Boyer and C.J. Gobler: The effects of temperature and nutrients on the growth and dynamics of toxic and non-toxic strains of Microcystis during cyanobacteria blooms. Harmful Algae, 8, 715-725 (2009).

Downing, T.G., C.S. Sember, M.M. Gehringer and W. Leukes: Medium $\mathrm{N}: \mathrm{P}$ ratios and specific growth rate comodulate microcystin and protein content in Microcystis aeruginosa PCC7806 and M. aeruginosa UV027. Microbial Ecology, 49, 468-473 (2005).

Giani, A., D.F. Bird, Y.T. Prairie and J.F. Lawrence: Empirical study of cyanobacterial toxicity along a trophic gradient of lakes. Canadian J. Fisher.Aqu. Sci., 62, 2100-2109 (2005).

Gobler, C.J., J.M. Burkholder, T.W. Davis, M.J. Harke, T. Johengen, C.A. Stow and D.B. Van de Waal: The dual role of nitrogen supply in controlling the growth and toxicity of cyanobacterial blooms. Harmful Algae, 54, 87-97 (2016).

Graham, J.L., J.R. Jones, S.B. Jones, J.A. Downing and T.E. Clevenger: Environmental factors influencing microcystin distribution and concentration in the Midwestern United States. Water Res., 38, 4395-4404 (2004).

Harke, M.J., D.L. Berry, J.W. Ammerman and C.J. Gobler: Molecular 
response of bloom-forming cyanobacterium, Microcystis aeruginosa to phosphorus limitation. Microbial. Ecol., 63 188-189 (2012).

Hesse, K. and J.G. Kohl: Effects of light and nutrient supply on growth and microcystin content of different strains of Microcystisaeruginosa. In: Cyanotoxins: Occurrence, causes, consequences (Ed.: I. Chorus). Springer, Berlin, pp. 104-114 (2001).

Horst, G.P., O. Sarnelle, J.D. White, S.K. Hamilton, R.B. Kaul and J.D. Bressie: Nitrogen availability increases the toxin quota of a harmful cyanobacterium, Microcystis aeruginosa. Water Res., 54, 188-198 (2014).

Kemp, A. and M.J. John: Microcystins associated with Microcystis dominated blooms in the Southwest wetlands, Western Australia. Environ. Toxicol., 21, 125-130 (2006).

Kim, I.J., S.H. Hong and J.Y. Jung: Establishment of effluent standards for industrial wastewaters in Korea: Current issues and suggestions for future plan. J. Water Environ. Tech., 8, 151-165 (2010).

Komárek, J. and K. Anagnostidis: Cyanoprokaryota 1. Teil: Chroococcales, In: Süßwasserflora von Mitteleuropa, 19/1. (Eds.: Ettl, H., G. Gartner, H. Heying and D. Mollenhauer). Gustav Fisher, Jena-Stuttgart-Lübeck-Ulm, pp. 224-235 (1999).

Lee, K.L., W.H. Jheong, J.M. Kim, Y.S. Kim, H.J. Choi and H.S. Kim: Seasonal variations of cyanobacterial toxins (microcystins) in Yeongchun reservoir. Korean J. Limnol. Soci., 41, 264-274 (2008).

Lee, K.L., K.Y. Jung, J.H. Kim, Y.S. Kim and H.S. Kim: Effect of nitrogen and phosphorus on growth and microcystin production in three Microcystis species. J. Environ. Biol., 39, 413-418 (2018)

Li, J., J. Zhang, W. Huang, F. Kong, Y. Li, M. Xi and Z. Zheng: Comparative bioavailability of ammonium, nitrate and urea to typically harmful cyanobacterium Microcystis aeruginosa. Marine Poll. Bull., 110, 93-98 (2016).

Lyck, S.: Stimultaneous changes in cell quotas of microcystin, chlorophyll a, protein and carbohydrate during different growth phases of a batch culture experiment with Microcystis aeruginosa. J. Plankton Res., 26, 727-736 (2004).

Long, B.M., G.J. Jones and P.T. Orr: Cellular microcystin content in Nlimited Microcystis aeruginosa can be predicted from growth rate. Appl. Environ. Microbiol., 67, 278-283 (2001).

Peng, G., S.W. Wilhelm, S. Lin and X. Wang: Response of Microcystis aeruginosa FACHB-905 to different nutrient ratios and changes in phosphorus chemistry. J. Oceanol. Limnol., 36, 1040-1052 (2018).

Pearl, H.W., H. Xu, M.J. McCarhty, G. Zhu, B. Qin and W.S. Gardner: Controlling harmful cyanobacterial blooms in a hyper-eutrophic lake (Lake Taihu, China): The need for a dual nutrient (N \& P) management strategy. Water Res., 45, 1973-1983 (2011).

Rantala, A., P. Rajaniemi-Wacklin, C. Lyra, L. Lepisto, J. Rintala, J. Mankiewicz-Boczek and K. Sivonen: Detection of microcystinproducing cyanobacteria in Finnish lakes with genus-specific microcystin synthetase gene $\mathrm{E}$ (mcyE) PCR and associations with environmental factors. Appl. Environ. Microbiol., 72, 6101-6110 (2006).

Sabour, B., M. Loudiki, B. Oudra, V. Vasconcelos, R. Martins, S. Oubraim and B. Fawzi: Toxicology of a Microcystis ichthyoblabe waterbloom from Lake Oued Mellah (Morocco). Environ. Toxicol., 17, 24-31 (2002).

Scott, J.T., M.J. McCarthy, T.G. Otten, M.M. Steffen, B.C. Baker, E.M. Grantz, S.W. Wilhelm and H.W. Paerl: Comment: An alternative interpretation the relationship between TN:TP and microcystin in Canadian lakes. Canadian J. Fisher. Aqu. Sci., 70, 1265-1268 (2013).

Šejnohová, L. and B. Maršálek: Microcystis. In: Ecology of Cyanobacteria 2: Their Diversity in Space and Time (Ed.: B.A. Whitton). Springer, New York, pp.195-228 (2012).

Tillett, D., D.L. Parker and B.A. Neilan: Detection for toxigenicity by a probe for the microcystin synthetase A gene $(m c y A)$ of the cyanobacterial genus Microcystis: Comparison of toxicities with $16 \mathrm{~S}$ rRNA and phycocyanin operon (phycocyanin intergenic spacer) phylogenies. Appl. Environ. Microbiol., 67, 2810-2818 (2001).

Via-Ordorika, L., J. Fastner, R. Kurmayer, M. Hisbergues, E. Dittmann, J. Komárek, M. Erhard and I. Chorus: Distribution of microcystinsproducing and non-microcystins-producing Microcystis sp. in European freshwater bodies: Detection of microcystins and microcystin genes in individual colonies. System. Appl. Microbiol., 27, 592-602 (2004).

Von Rückert, G. and A. Giani: Effect of nitrate ammonium on the growth and protein concentration of Microcystis viridis Lemmermann (Cyanobacteria). Revista Brasileira De Bottanica, 27, 325-331 (2004).

World Health Organization.: Guidelines for Drinking-water Quality. $4^{\text {th }}$ Edn., Incorporating the first addendum. WHO (2017). 